Keywords:

Endangered species

Ca oxalate crystals

X-ray spectroscopy

Scanning electron microscopy

Histórico:

Recebido 23/02/2017

Aceito 30/05/2017

Palavras chave: Espécie ameaçada

Cristais de oxalato de $\mathrm{Ca}$

Espectroscopia de raios- $X$

Microscopia eletrônica de varredura

+Correspondência: barbosajz@yahoo.com.br

DOI: | $0.1590 / 0104776020172302313$
Julierme Zimmer Barbosa'+, Valdeci Constantino', Flávio Zanette', Antonio Carlos Vargas Motta', Stephen Arthur Prior ${ }^{2}$

\section{SOIL FERTILITY AFFECTS ELEMENTAL DISTRIBUTION IN NEEDLES OF THE CONIFER Araucaria angustifolia: A MICROANALYTICAL STUDY}

ABSTRACT: Araucaria angustifolia is a conifer species found in South American subtropical forests that comprises less than $3 \%$ of the native vegetation and little is known concerning the accumulation of nutritional elements in its needles. In this study, scanning electron microscopy (SEM) coupled with energy dispersive spectroscopy (EDS) was used to assess the elemental distribution in needles. Needles were selected from 28 month-old plants grown in a fertilization experiment supplied with: I) $\mathrm{N}, \mathrm{P}$, and $\mathrm{K}$; 2) $\mathrm{N}$ and $\mathrm{P}$; and 3) $\mathrm{N}$ and $\mathrm{K}$. In microanalysis, four types of specialized needle tissues (adaxial epidermis, palisade mesophyll, spongy mesophyll and abaxial epidermis) were evaluated for elemental composition ( $\mathrm{C}, \mathrm{O}, \mathrm{P}, \mathrm{K}, \mathrm{Ca}, \mathrm{S}$ and $\mathrm{Al}$ ). When crystals were detected, the concentrations of 12 elements were determined (C, O, P, K, Ca, S, Al, Fe, Mg, Na, Si, and $\mathrm{Cl}$ ). Under low soil $\mathrm{P}$ and $\mathrm{K}$, these elements were found in low concentrations in the epidermis, mesophyll, and crystals. Under low soil P, Ca and K accumulated in the spongy mesophyll, while under low soil $\mathrm{K}$ only $\mathrm{Ca}$ accumulated in this tissue. In addition, low soil $\mathrm{P}$ or $\mathrm{K}$ availability favored the formation of crystals; crystals under low soil $\mathrm{K}$ availability had more $\mathrm{Ca}$ and $\mathrm{Mg}$. Soil $\mathrm{P}$ and $\mathrm{K}$ availability affected the distribution of elements in needles of $A$. angustifolia, in that type of tissue and formation of crystals were key to the nutrient dynamics in needles.

\section{FERTILIDADEDOSOLOAFETAADISTRIBUIÇÃODEELEMENTOSEMACÍCULAS DA CONÍFERA Araucaria angustifolia: UM ESTUDO MICROANALÍTICO}

RESUMO: Espécie da floresta subtropical da América do Sul e restando apenas menos de $3 \%$ de vegetação natural, a Araucaria angustifolia é ainda pouco conhecida sobre a distribuição de elementos em suas acículas. Nesse estudo, utilizamos microscopia eletrônica de varredura (MEV) com espectroscopia por dispersão de energia (EDS) para avaliar a distribuição elementar em acículas de A. angustifolia. Foram selecionadas acículas de plantas (28 meses de idade) cultivadas em experimento de adubação: com suprimento de N, P e K; com N e P; com $\mathrm{N}$ e K. Na microanálise quatro tipos de tecidos especializados das acículas (epiderme superior, mesófilo paliçádico, mesófilo esponjoso e epiderme inferior) foram avaliados quanto a composição (C, O, P, K, Ca, S e Al). Quando foram detectados cristais determinaram-se as concentrações de 12 elementos ( $C, O, P, K$, $\mathrm{Ca}, \mathrm{S}, \mathrm{Al}, \mathrm{Fe}, \mathrm{Mg}, \mathrm{Na}, \mathrm{Si}$ e Cl). $\mathrm{Na}$ baixa disponibilidade de $\mathrm{P}$ e K, esses elementos foram encontrados em baixas concentrações na epiderme, no mesófilo e em cristais. Na baixa disponibilidade de $\mathrm{P}$ ocorreu acúmulo de $\mathrm{Ca}$ e $\mathrm{K}$ no mesófilo esponjoso, enquanto que na baixa disponibilidade de $\mathrm{K}$ ocorreu acúmulo de Ca no mesófilo esponjoso. Em adição, a baixa disponibilidade de $\mathrm{K}$ e $\mathrm{P}$ favoreceu a formação de cristais, sendo que em baixa disponibilidade de $\mathrm{K}$, os cristais apresentaram mais $\mathrm{Ca}$ e $\mathrm{Mg}$. A disponibilidade de $\mathrm{P}$ e K no solo afetou a distribuição de elementos em acículas de $A$. angustifolia, sendo que o tipo de tecido e a formação de cristais foi chave para a dinâmica de nutrientes nas acículas.

' Federal University of Paraná - Curitiba, Paraná, Brazil

2 National Soil Dynamics Laboratory, United States Department of Agriculture, Auburn, AL, United States 


\section{INTRODUCTION}

Araucaria angustifolia (Bert.) O. Ktze, popularly known as araucaria, Brazilian pine, or Paraná pine, is one of the most important native species in southern Brazil. Originally it covered large continuous areas in southern Brazil (Paraná, Santa Catarina and Rio Grande do Sul states), extending north to São Paulo, Minas Gerais and Rio de Janeiro where they are found in small isolated patches, especially in colder and higher regions of these states. Some isolated individuals are also found in northern Argentina and eastern Paraguay. In the Atlantic Forest area, it is a component of the Mixed Ombrophilous Forest (also called the Araucaria Forest). However, today A. angustifolia is on the endangered species list (REIS et al., 20I4).

The seeds (pinhão) of $A$. angustifolia have economic and social importance, especially in states where edible seeds obtained from natural stands provide hundreds of families with a main source of annual income. In addition, A. angustifolia also has ecological importance since its seeds are the main food for many mammals and birds in the winter and its presence creates a microclimate that favors the development of many species (REIS et al., 2014; PERALTA et al., 2016). Factors such as historical timber cutting and seed removal have hindered natural forest reestablishment.

Generally, A. angustifolia is nutrient demanding, especially for the nutrients $\mathrm{K}$ and $\mathrm{P}$, which are among the most demanded by this plant (SIMÕES; COUTO, 1973). Therefore, under cultivation application of these two nutrients represents a considerable cost. In studies with $A$. angustifolia, elemental composition analysis has been used to assess nutritional status and plant/water relationships (GARBIN; DILLENBURG 2008; CASSANA; DILLENBURG, 2013). However, use of total needle elemental concentrations can have limited use in the study of plant metabolism because tissue types within the needles may have variable composition (REGVAR et al., 2013; CARVALHO et al., 2016).

Advanced microscopy and spectroscopy techniques have allowed for a more comprehensive assessment of the elemental composition of plant tissues (DINH et al., 20I5; KRIEGER et al., 20I7). In the evaluation of elemental accumulation, studies have concentrated on the elemental distribution in different tissues and plant cells (CONN; GILLIHAM, 20I0) including crystals (HE et al., 20I4). In such cases, SEM combined with EDS has been used efficiently in the microanalysis of essential and potentially toxic elements in plant tissues (SILVA et al., 20I4; HE et al., 2015; KRIEGER et al., 2017). However, there is a paucity of information on elemental accumulation in A. angustifolia needles. Thus, our study objective was to assess the elemental accumulation profile of $A$. angustifolia needles grown in soil that varied in $\mathrm{P}$ and $\mathrm{K}$ nutrient availability.

\section{MATERIAL AND METHODS}

\section{Plant growth conditions}

The study was conducted in a nursery (open sky) in the city of Curitiba, Paraná, Brazil (latitude -25.4I2; longitude -49.428, altitude 91 $1 \mathrm{~m}$ ) located at Federal University of Paraná (Sector of Agricultural Sciences). The soil used for seedling growth was a Cambisol collected from an area where $A$. angustifolia naturally occurs in Pinhais, Paraná. The soil, at field moisture, was sieved (4 $\mathrm{mm}$ ), homogenized, and sampled for analysis (Table I).

Based on soil chemical analysis, dolomitic lime was applied (3.6 g per $\mathrm{kg}$ of soil with a relative total neutralization power of $75.2 \%$ ) to increase base saturation to $70 \%$ (using the method of base saturation). The soil was then homogenized and incubated for two months (time when the reaction of limestone in the soil tends to stabilize). After this incubation period, the soil was again homogenized and $16 \mathrm{dm}^{3}$ were placed in 20 $\mathrm{dm}^{3}$ containers (height $=30 \mathrm{~cm}$; bottom diameter $=$ $25 \mathrm{~cm}$; top diameter $=35 \mathrm{~cm}$ ). Three treatments with four replications based on CQFS/RS-SC (2004) were evaluated: I) control, soil with high $\mathrm{P}$ and $\mathrm{K}$ availability (N-P-K = 22.2, I8.3, and I 2.5 g per container); 2 ) -K, soil with low $\mathrm{K}$ availability (N-P-K $=22.2,18.3$, and $0 \mathrm{~g}$ per container); and 3 ) -P, soil with low $\mathrm{P}$ availability (N-P-K $=22.2$, 0 , and $12.5 \mathrm{~g}$ per container). The complete amounts of $\mathrm{P}$ and $\mathrm{K}$ were mixed into the soil. Half of the total $\mathrm{N}$ was initially mixed into the soil; the other half was top-dressed in a split manner at 12 (50\%), I4 (30\%) and $16(20 \%)$ months after seedlings were transplanted. The sources used to supply N-P-K were urea (45\% $\mathrm{N})$, super triple phosphate $\left(4 \mathrm{I} \% \mathrm{P}_{2} \mathrm{O}_{5}\right)$, and $\mathrm{KCl}(60 \%$ $\mathrm{K}_{2} \mathrm{O}$ ), respectively.

In December 2013, a seven month old seedling ( $\sim 20 \mathrm{~cm}$ tall) was transplanted into each container. Containers were randomly distributed on a plastic surface to avoid contact and interference from surrounding soil. Weed control was done manually and irrigation (2 $L \cdot$ plant $^{-1}$ at 9:00 AM) occurred during periods without adequate rainfall.

Twenty-one months after seedlings were transplanted (September 2015), trees had an average height of 88,75 , and $60 \mathrm{~cm}$ for the control, $-\mathrm{K}$, and - $P$ treatments, respectively. At this time, Mehlich-I 
TABLE I Granulometric and chemical properties of the soil.

\begin{tabular}{|c|c|c|c|c|c|c|c|c|c|c|c|c|c|}
\hline Sand' & Silt & Clay & $\mathrm{pH}$ & $\mathrm{Ca}^{2+}$ & $\mathrm{Mg}^{2+}$ & $\mathrm{K}^{+}$ & $\mathrm{Al}^{3+}$ & $\mathrm{H}^{+} \mathrm{Al}^{3+}$ & CEC & BS & $\mathrm{m}$ & $\mathrm{P}$ & OC \\
\hline 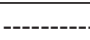 & $\mathrm{kg}^{-1}$ & -.-- & & & -----.-. & --- & $d \cdot d m^{-}$ & 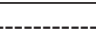 & -- & $\%$ & $\%$ & $\mathrm{mg} \cdot \mathrm{dm}^{-3}$ & $g \cdot \mathrm{dm}^{-3}$ \\
\hline 238 & 213 & 550 & 4.0 & 1.60 & 0.80 & 0.08 & 2.90 & 11.30 & 13.78 & 18 & 54 & 0.90 & 4.20 \\
\hline
\end{tabular}

' Before analysis soil was re-sieved $(2 \mathrm{~mm})$ and dried at $40^{\circ} \mathrm{C}$; Sand, silt, and clay (hydrometer method); $\mathrm{pH}\left(\mathrm{CaCl}_{2} 0.0 \mathrm{l} \mathrm{mol} \cdot \mathrm{L}^{-1}\right) ; \mathrm{Ca}^{2+}, \mathrm{Mg}^{2+}, \mathrm{Al}^{3+}(\mathrm{extracted}$ with $\mathrm{KCl}$ I mol- $\left.\mathrm{L}^{-1}\right) ; \mathrm{H}^{+} \mathrm{Al}{ }^{3+}$ (calcium acetate $0.5 \mathrm{~mol} \cdot \mathrm{L}^{-1}$ extraction); organic carbon (OC) (volumetric method by potassium dichromate); $\mathrm{K}^{+}$and $\mathrm{P}($ Mehlich- $\mathrm{I}$ extraction); base saturation (BS); cation exchange capacity $(\mathrm{CEC})$ at $\mathrm{pH} 7$; and $\mathrm{Al}^{3+}$ saturation $(\mathrm{m})$. All analyzes were based on Embrapa (20I I).

extractions showed that the respective soil $K$ and $P$ levels were $0.33 \mathrm{cmol} \cdot \mathrm{dm}^{-3}$ (or $128 \mathrm{mg} \cdot \mathrm{dm}^{-3} \mathrm{~K}$ ) and $50 \mathrm{mg} \cdot \mathrm{dm}^{-3}$ for the control treatment, $0.06 \mathrm{cmol}_{c} \cdot \mathrm{dm}^{-3}$ (or $23 \mathrm{mg} \cdot \mathrm{dm}^{-3} \mathrm{~K}$ ) and $35 \mathrm{mg} \cdot \mathrm{dm}^{-3}$ for the $-\mathrm{K}$ treatment and, $0.40 \mathrm{cmol}_{c} \cdot \mathrm{dm}^{-3}$ (or $156 \mathrm{mg} \cdot \mathrm{dm}^{-3} \mathrm{~K}$ ) and 1.4 $\mathrm{mg} \cdot \mathrm{dm}^{-3}$ for the $-\mathrm{P}$ treatment. In addition, needle elemental composition confirms the low soil $\mathrm{K}$ and $\mathrm{P}$ availability (Table 2).

\section{SEM-EDS microanalysis}

In September 2015, needles were collected (uninjured and free from symptoms of disease) from the central region of branches in the third whorl from the crown apex. The needles were washed in deionized water and $\sim 2 \mathrm{~mm}$ wide cross-sections from the central region of the needles were removed with a stainless steel blade. Needle sections were fixed in FAA medium (5\% [v/v] formalin, $5 \%[\mathrm{v} / \mathrm{v}]$ glacial acetic acid and $70 \%[\mathrm{v} / \mathrm{v}]$ ethanol) for $24 \mathrm{~h}$ in the dark at $4^{\circ} \mathrm{C}$. After fixation, sections were dehydrated in an ascending ethanol series of 70,80 , 90,95 , and $100 \%$ for I hour and dehydrated to critical point with liquid $\mathrm{CO}_{2}$. The sections were then mounted on aluminum stubs coated with double-sided copper tape. The microanalyses were performed using SEM (Vega3 LM, Tescan) with EDS (X-Max ${ }^{\mathrm{N}}$, Oxford). The SEM instrument was a thermionic emission system with a tungsten heated filament as the electron source with a resolution of $3 \mathrm{~nm}$, and microscope functions were controlled via VegaTC software. The EDS instrument contained an $80 \mathrm{~mm}^{2}$ silicon drift detector, and data processing was conducted with AZTech (Advanced) software.
Four points of needle cross sections (adaxial epidermis, palisade mesophyll, spongy mesophyll and abaxial epidermis; Figure I) were selected for determination of elemental composition. Subsequently, the elemental composition of crystals found in needle mesophyll was determined. The images were obtained with accelerating voltage of $15 \mathrm{kV}$ in low vacuum. Microanalyses by EDS were conducted with accelerating voltage of $15 \mathrm{kV}, 35^{\circ}$ takeoff angle, and I $20 \mathrm{~s}$ per time point. In general, a maximum of twelve elements were detected (C, O, $\mathrm{Na}, \mathrm{Mg}, \mathrm{Al}, \mathrm{Si}, \mathrm{P}$, $\mathrm{S}, \mathrm{Cl}, \mathrm{K}, \mathrm{Ca}$ and $\mathrm{Fe}$ ); these elements were analyzed based on $\mathrm{K}-\alpha$ lines and the use of internal standards $\left(\mathrm{C} . \mathrm{Vit}, \mathrm{SiO}_{2}\right.$, $\mathrm{NaAlSi}_{3} \mathrm{O}_{8}, \mathrm{MgO}, \mathrm{Al}_{2} \mathrm{O}_{3}, \mathrm{SiO}_{2}, \mathrm{GaP}, \mathrm{FeS}_{2}, \mathrm{NaCl}, \mathrm{KBr}, \mathrm{CaSiO}_{3}$ and $\mathrm{Fe}$, respectively).

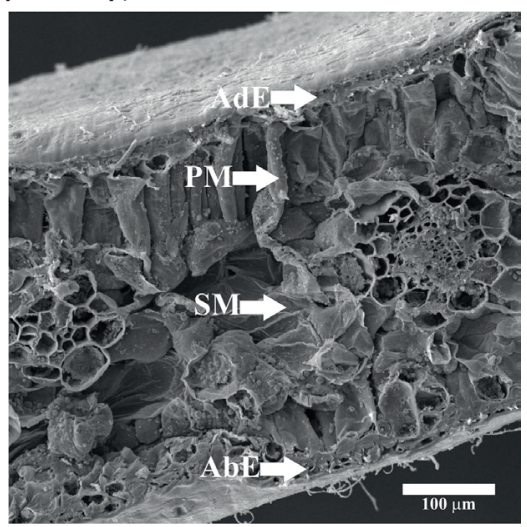

FIGURE I Photomicrograph of a needle cross section of Araucaria angustifolia indicating the microanalysis points. The image was obtained via scanning electron microscope in high vacuum and after Au plating. The elemental microanalyses were obtained with energy dispersive spectroscopy. AdE = adaxial epidermis; $\mathrm{PM}=$ palisade mesophyll; $\mathrm{SM}=$ spongy mesophyll; and $\mathrm{AbE}=$ abaxial epidermis.

TABLE 2 Mean and standard deviation of the concentration of elements in needles of Araucaria angustifolia low P (-P), low K (-K), and control (high soil $\mathrm{P}$ and $\mathrm{K}$ ) treatments.'

\begin{tabular}{cccccccc}
\hline Treatments & $\mathrm{K}$ & $\mathrm{Ca}$ & $\mathrm{Mg}$ & $\mathrm{P}$ & $\mathrm{Fe}$ & $\mathrm{Mn}$ & $\mathrm{Zn}$ \\
\hline Control & $13,255 \pm 2,03 \mathrm{I}$ & $7,660 \pm 304$ & $2,942 \pm 332$ & $\mathrm{I}, 793 \pm 168$ & $79 \pm 14$ & $103 \pm 26$ & $14 \pm 2.76$ \\
$-\mathrm{K}$ & $4,778 \pm 357$ & $24,624 \pm 4,644$ & $6,305 \pm 94 \mathrm{I}$ & $1,559 \pm 99$ & $101 \pm 30$ & $427 \pm 160$ & $14 \pm 2.75$ \\
$-\mathrm{P}$ & $14,878 \pm 96 \mathrm{I}$ & $9,022 \pm \mathrm{I}, 542$ & $2,904 \pm 310$ & $1,112 \pm 64$ & $104 \pm 27$ & $165 \pm 88$ & $15 \pm 4.18$ \\
\hline & $\mathrm{Cu}$ & $\mathrm{B}$ & $\mathrm{Cr}$ & $\mathrm{Si}$ & $\mathrm{Al}$ & $\mathrm{Ba}$ & $\mathrm{Ti}$ \\
\hline Control & $\mathrm{I} .94 \pm 0.22$ & $10 \pm \mathrm{I} .86$ & $0.66 \pm 0.19$ & $96 \pm 9$ & $75 \pm 9$ & $\mathrm{II} \pm 0.96$ & $1.83 \pm 0.43$ \\
$-\mathrm{K}$ & $2.67 \pm 0.48$ & $15 \pm 1.89$ & $0.34 \pm 0.08$ & $135 \pm 35$ & $109 \pm 40$ & $26 \pm 4$ & $1.40 \pm 0.49$ \\
$-\mathrm{P}$ & $2.57 \pm 0.47$ & $19 \pm 2.87$ & $1.77 \pm 1.15$ & $115 \pm 25$ & $98 \pm 26$ & $19 \pm 6$ & $1.27 \pm 0.25$ \\
\hline
\end{tabular}

' Unit of elements is $\mathrm{mg} \cdot \mathrm{kg}^{-1}$ and the analytical procedure was: $\sim 200 \mathrm{mg}$ of needles (oven dried, ground and passed through a I mm sieve) was digested in $6 \mathrm{ml}$ of $\mathrm{HNO}_{3}$ + water mixture (ratio 2:I, v/v) and $2 \mathrm{ml} \mathrm{H}_{2} \mathrm{O}_{2}(30 \%)$ using a microwave heating system (MARS, CEM Microwave Technology Ltd); once digestion was complete, the tubes were cooled and brought to a volume of $25 \mathrm{~mL}$ by adding Milli- $\mathrm{Q}$ water; subsequent total elemental analysis was carried out by flame emission spectroscopy (DM62, Digimed) for $\mathrm{K}$, while the other elements ( $\mathrm{Ca}, \mathrm{Mg}, \mathrm{P}, \mathrm{Fe}, \mathrm{Mn}, \mathrm{Zn}, \mathrm{Cu}, \mathrm{B}, \mathrm{Si}, \mathrm{Cr}, \mathrm{Al}, \mathrm{Ba}, \mathrm{Ti})$ were determined using an optical emission spectrometer with inductively coupled plasma (ICP-OES) (720-ES, Varian). 
To estimate the number of crystals found within A. angustifolia needles, the following procedure was performed: five squares $(0.1 \times 0.1 \mathrm{~mm})$ were arranged diagonally across each needle section; the number of crystals within each square was counted; the mean and standard deviation of crystal numbers were obtained considering five squares in four replicates per treatment (totaling 20 squares per treatment).

\section{Statistical analysis}

Relative elemental concentration data from specialized tissues of $A$. angustifolia needles were analyzed in a completely randomized design in split plot with four replications. The three fertility treatments (control, $-\mathrm{K}$ and $-\mathrm{P}$ ) were considered as main plots and the four types of specialized tissues (adaxial epidermis, palisade mesophyll, spongy mesophyll and abaxial epidermis) were considered sub-plots. Data were subjected to analysis of variance and means were compared by Tukey test at $5 \%$ probability. Statistical analyzes were performed with Sisvar software (FERREIRA, 20l I).

\section{RESULTS AND DISCUSSION}

\section{Elemental distribution in epidemis and mesophyll}

The $\mathrm{P}, \mathrm{K}$, and $\mathrm{Ca}$ relative concentrations in the four specialized tissues are shown in Figure 2 . The -P microanalysis values are related to the low total concentration of that nutrient in needles (Table 2). Unlike the present study where there was no variation among the specialized tissues, Conn and Gilliham (2010) reported that monocots accumulate $\mathrm{P}$ in the mesophyll, while dicots accumulate $P$ in the epidermis. In addition, - $P$ was the only treatment in which this element was not detected in the spongy mesophyll and abaxial epidermis (Figure 2a). This suggests that under deficiency conditions, $P$ was either discharged directly from the xylem to the
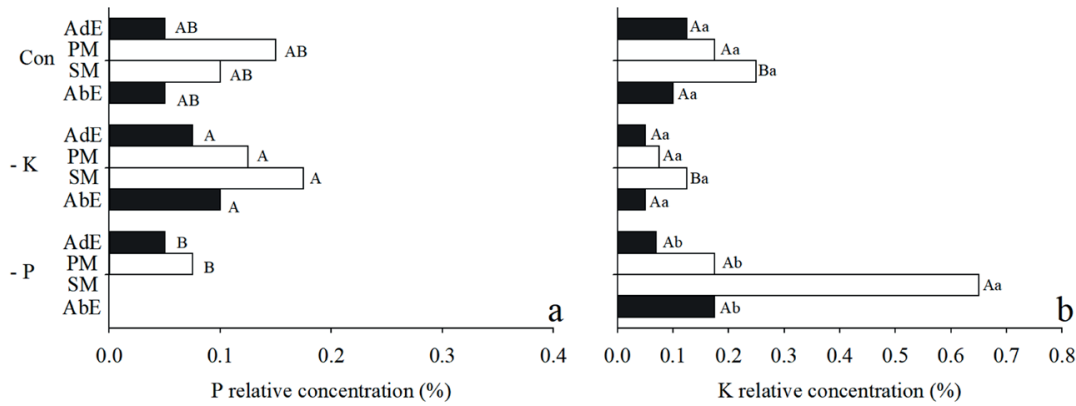

FIGURE 2 Relative concentration (\%) of $\mathrm{P}(\mathrm{a}), \mathrm{K}(\mathrm{b})$ and $\mathrm{Ca}(\mathrm{c})$ in the adaxial epidermis (AdE), palisade mesophyll (PM), spongy mesophyll (SM) and abaxial epidermis (AbE) in needles of $A$. angustifolia grown under low $\mathrm{P}(-\mathrm{P})$, low $\mathrm{K}(-\mathrm{K})$ and control conditions with high soil $\mathrm{P}$ and $\mathrm{K}$ availability (Con). Uppercase letters (nutritional status effect) followed by the same letters and lowercase letters (specialized tissue effect) followed by the same letters do not differ by Tukey test $(p<0.05)$.

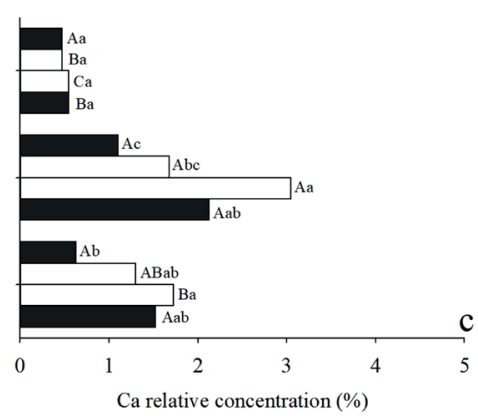

(KARLEY et al., 2003), or the opposite occurred without preferential distribution to other tissues. Clearly, further studies with SEM-EDS are required to further understand $P$ dynamics in $A$. angustifolia needles.

In $A$. angustifolia grown under $-\mathrm{P}$, the $\mathrm{K}$ relative concentration in the spongy mesophyll of needles was higher than other specialized tissues and when compared to the control and $-\mathrm{K}$ treatments (Figure $2 \mathrm{~b}$ ). The $-\mathrm{P}$ treatment also increased $\mathrm{K}$ concentration in the needles (Table 2). Thus, it is possible that low $\mathrm{P}$ favored the xylem $\mathrm{K}$ offload to the mesophyll through the vascular sheath (KARLEY et al., 2003). Findings may be related to the low plant growth in soil with low $\mathrm{P}$ availability. However, it is important to note that the $\mathrm{K}$ relative concentrations determined by EDS were low (being near that of $P$ ); this was in opposition to total concentrations (Table 2) where $K$ was $\sim 13$ times higher than $P$ concentration. This result may indicate that part of the $\mathrm{K}$ was lost during tissue fixation since this element is mainly in free forms in plant cells (TAIZ et al., 20I5).

Considering the variation among treatments, $\mathrm{Ca}$ results from EDS microanalysis (Figure $2 c$ ) followed the same trend as total $\mathrm{Ca}$ concentrations in needles (Table 2 ). In other words high concentrations were noted in the -K treatment. The competition between $\mathrm{Ca}$ and $\mathrm{K}$ for absorption through the root system (where the lack of one favors absorption of the other) is well known in the literature and has been reported by Simões and Couto (1973) for A. angustifolia. Regarding $\mathrm{Ca}$ accumulation in spongy mesophyll, Rios et al. (2012) found that Ca accumulated in the palisade mesophyll of Brassica rapa leaves when the nutrient solution availability was high, whereas under low Ca availability the distribution in leaves was homogeneous. However, $\mathrm{Ca}$ accumulation sites can vary among species: mesophyll for dicots (CONN; GILLIHAM, 2010); and epidermis and mesophyll for the 
Zn/Cd hyperaccumulator species Noccaea caerulescens (DINH et al., 20I5).

The $\mathrm{C}$ and $\mathrm{O}$ relative concentrations in specialized A. angustifolia needle tissues followed this descending order: adaxial epidermis > abaxial epidermis > mesophyll palisade $>$ spongy mesophyll and, spongy mesophyll $>$ abaxial epidermis $>$ mesophyll palisade $>$ adaxial epidermis, respectively (Figure $3 \mathrm{a}, \mathrm{b}$ ). The differentiation in $\mathrm{C}$ and O concentrations between the epidermis and mesophyll is mainly due to the biochemical composition of each specialized tissue type. Regarding the composition, the epidermis consists of structural biomolecules (i.e., lignin, cellulose and pectin) which are rich in $\mathrm{C}$ and higher than that found in the mesophyll (REGVAR et al., 20I3). Biologically, it can be inferred that these results are congruent with the functionality of each cell type. Accordingly, higher C concentrations of biomolecules confer resistance to the outer layers of needle tissue (epidermis, especially the adaxial epidermis) thereby protecting the inner layers (mesophyll) which are responsible for photosynthesis (TAIZ et al., 20I5).

The $S$ relative concentrations in the specialized tissues of $A$. angustifolia needles ranged from $0.05 \%$ to $0.42 \%$, being higher in the palisade mesophyll compared to the other specialized tissues (Figure 3c). These results indicate that in palisade mesophyll there is a greater accumulation of organic molecules containing S. Likewise, Mastroberti and Mariath (2003) reported an accumulation of phenolic compounds and a large number of chloroplasts in A. angustifolia; both generally
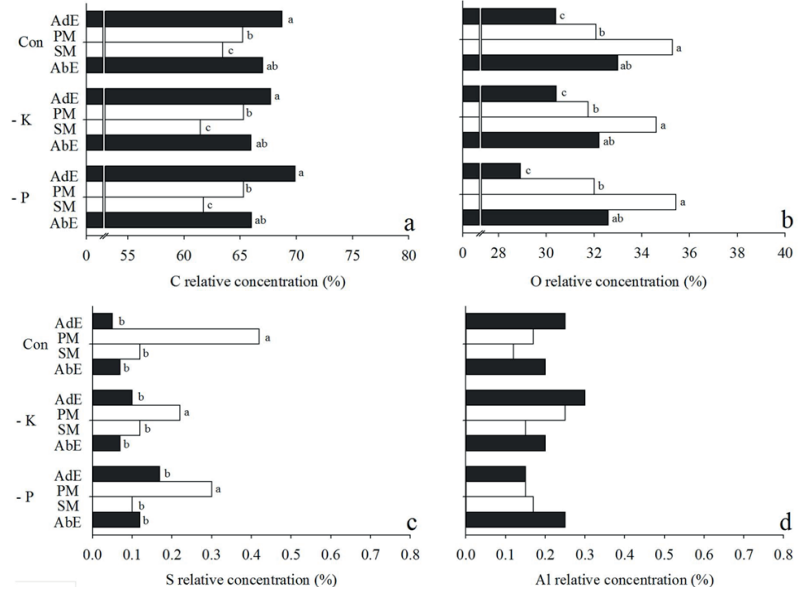

FIGURE 3 Relative concentration (\%) of C (a), O (b), S (c) and $\mathrm{Al}(\mathrm{d})$ in the adaxial epidermis (AdE), palisade mesophyll (PM), spongy mesophyll (SM) and abaxial epidermis $(A b E)$ in needles of $A$. angustifolia grown under low $\mathrm{P}(-\mathrm{P})$, low $\mathrm{K}(-\mathrm{K})$ and control conditions with high soil $P$ and $K$ availability (Con). Uppercase letters (nutritional status effect) followed by the same letters and lowercase letters (specialized tissue effect) followed by the same letters do not differ by Tukey test $(p<0.05)$. contain S in their composition. Conn and Gilliham (2010) also reported higher $\mathrm{S}$ concentrations in the mesophyll compared to the epidermis of monocot and dicot leaves.

In general, the $\mathrm{Al}$ relative concentrations ranging from $0.12 \%$ to $0.30 \%$ were not significantly affected by specialized tissue type or nutritional status (Figure $3 \mathrm{~d}$ ). However, further studies are needed to evaluate the distribution of $\mathrm{Al}$ in needles of this species under other conditions (e.g., a greater diversity of soils). Considering the total concentration of $\mathrm{Al}$ in needles, observed values (Table I; on average $94 \mathrm{mg} \cdot \mathrm{kg}^{-1}$ ) were similar to those reported by Reissmann et al. (1976) (on average I $36 \mathrm{mg} \cdot \mathrm{kg}^{-1}$ ), which are relatively low concentrations. In plants that tolerate high $\mathrm{Al}$ concentrations in leaves (such as tea Camellia sinensis (L.) O. Kuntze a mean Al concentration: $\left.6,866 \mathrm{mg} \cdot \mathrm{kg}^{-1}\right)$, it is often accumulated in the epidermis (CARR et al., 2003). For a wide range of species that accumulate metals in leaves, Leitenmaier and Küpper (2013) observed that the principal accumulation site is the epidermis. Under the most common condition (accumulation in the epidermis), it is likely that metals cannot be discharged from the rib xylem to the mesophyll symplastically, thus, they are carried by rib extensions to the epidermis apoplastically (KARLEY et al., 2003).

\section{Crystal formation and precipitation of elements}

During microanalysis of $A$. angustifolia needles with contrasting nutritional status, various crystals were seen in photomicrographs (Figure 4). It was noted that needles from the $-K$ treatment had a higher density of crystals $\left(3,400 \pm 900\right.$ crystals $\left.\mathrm{mm}^{2}\right)$ compared to other treatments. For the $-\mathrm{P}$ treatment $(1,800 \pm 800$ crystals $\mathrm{mm}^{2}$ ), needles were found to have more crystals than the control treatment $\left(900 \pm 300\right.$ crystals $\left.\mathrm{mm}^{2}\right)$.

There is evidence in our study for the regulation of $\mathrm{Ca}$ availability in needles since the high density of crystals in needles $-\mathrm{K}$ treatment (Figure $4 \mathrm{~b}$ ) was due to a higher total Ca concentration $\left(24,624 \mathrm{mg} \cdot \mathrm{kg}^{-1}\right)$ in needles (Table 2). In addition, the higher crystal density in the -P treatment (vs. control; Figure 4a) can be explained by variation in the total Ca concentration (-P $=9,022 \mathrm{mg} \cdot \mathrm{kg}^{-1}$; control $=7,660 \mathrm{mg} \cdot \mathrm{kg}^{-1}$ ) in the needles (Table 2). In needles of a conifer species Picea abies (L.) Karst., Fink (I99I) found that the water soluble $\mathrm{Ca}$ concentration did not vary with element availability despite a wide variation in Ca-oxalate concentration (acid soil: I,269 $\mathrm{mg} \cdot \mathrm{kg}^{-1} \mathrm{Ca}$; calcareous soil: $8,712 \mathrm{mg} \cdot \mathrm{kg}^{-1} \mathrm{Ca}$ ) after extraction with $\mathrm{HCl}$. In the same study, the authors found $\mathrm{Ca}$ crystals occurring in the extracellular portion of the intercellular spaces along the cell wall. Pritchard et al. (2000) found 

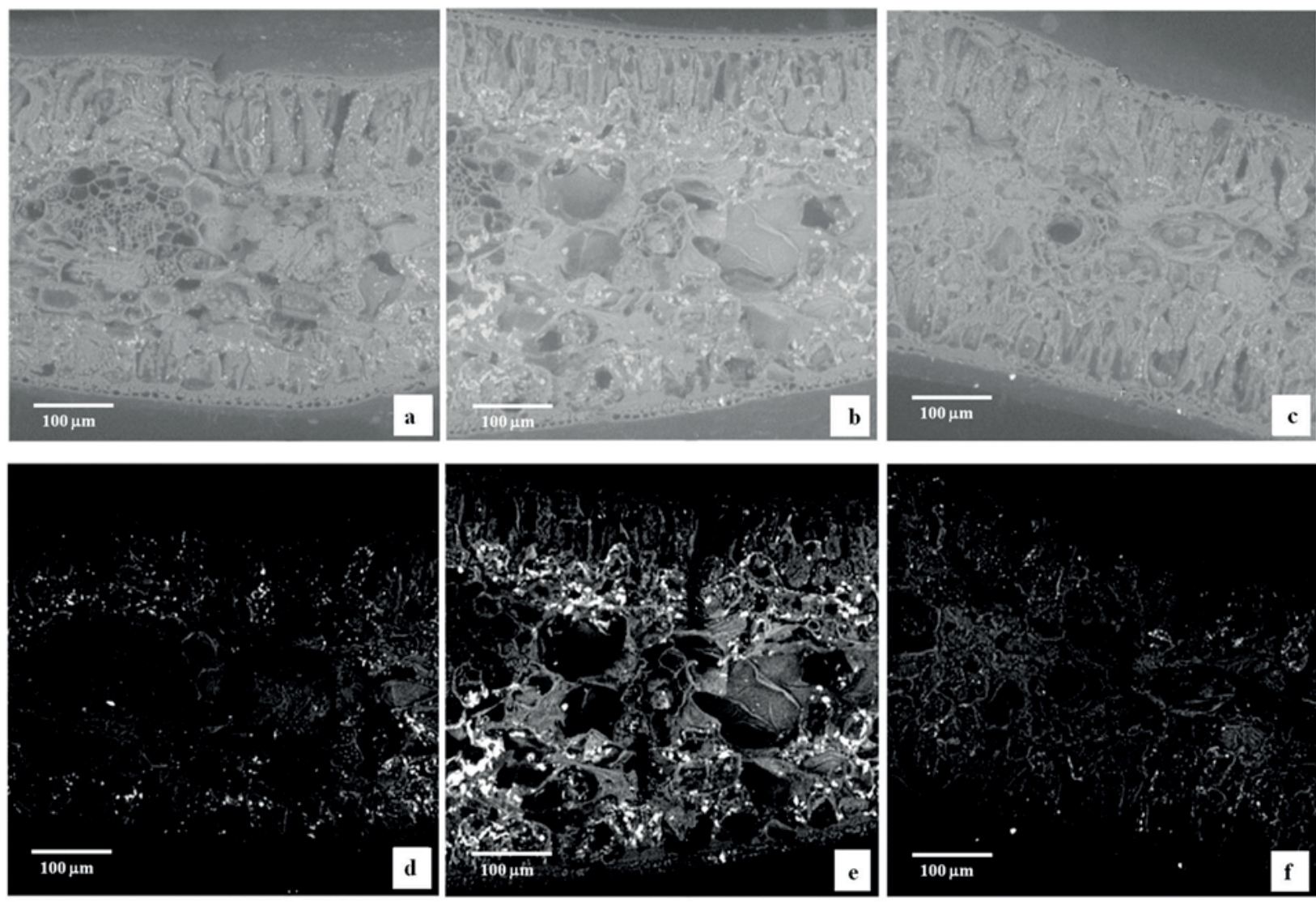

FIGURE 4 Photomicrographs of needles (in cross section) of $A$. angustifolia. Plants were grown under low P (a; d), low K (b; e) and control conditions (with $\mathrm{P}$ and $\mathrm{K}$ ) (c; f). a-c: photomicrographs taken with a scanning electron microscope at low vacuum. $d$-f: are the same photomicrographs a-c with brightness reduction (-40\%) and increased contrast (80\%).

extracellular $\mathrm{CaSO}_{4}$ crystals in substomatal cavities of longleaf pine (Pinus palustris Mill.) which were not impacted by resource availability (e.g., nitrogen, water, or atmospheric $\mathrm{CO}_{2}$ level). Note that the crystals found were probably $\mathrm{Ca}$-oxalate since $\mathrm{Ca}$-carbonate crystals usually do not resist the sample fixation process when the solution contains acetic acid (LERSTEN; HORNER, $20 \mathrm{II}$ ), as in this study.

In general, the main elements contained in the crystals were $\mathrm{C}, \mathrm{O}$, and $\mathrm{Ca}$. These three elements comprised $98 \%$ of the crystals on average (Figure 5; Table 3). With respect to $\mathrm{C}$ and $\mathrm{Ca}$, it was possible to verify crystal differences according to the nutritional status of $A$. angustifolia. In the $-K$ treatment, the relative concentrations of $\mathrm{C}$ and $\mathrm{Ca}$ of two crystals (numbers 2 and 3) were lower and higher, respectively, compared to the crystals (I, 2, and 3) of the other treatments. Therefore, needles with higher $\mathrm{Ca}$ concentration (Table 2 ) and crystal density (Figure 4) had crystals richer in $\mathrm{Ca}$. These results support the importance of Ca crystal formation in regulating the availability of this element ( $\mathrm{HE}$ et al., 20I4). This indicates that A. angustifolia is probably an oxalic plant regarding $\mathrm{Ca}$ physiological nutrition (WHITE, 2005).

Regarding other elements detected in crystals, only $\mathrm{P}, \mathrm{K}$, and $\mathrm{Mg}$ (Table 3 ) exhibited an influence of nutritional status. In the -P treatment, none of the crystals showed $\mathrm{P}$ in their constitution. In the $-\mathrm{K}$ treatment, only one crystal was found to contain $\mathrm{K}$ and was the only treatment where $\mathrm{Mg}$ was detected in the needle crystals. Thus, due to low soil $\mathrm{P}$ and $\mathrm{K}$ there was no significant incorporation of these elements in crystal structures which corresponds with the low total concentrations in A. angustifolia needles (Table 2). On the other hand, plants grown under -K (Table 3) incorporated $\mathrm{Mg}$ and $\mathrm{Si}$ into the crystal structure due to an increase in the total $\mathrm{Mg}$ (and secondarily $\mathrm{Si}$ ) concentration in the needles. Although the concentrations of $\mathrm{P}, \mathrm{Mg}$, and $\mathrm{Si}$ in crystals are low and similar to those seen in cellular structures, it is likely that the crystal formation process can influence the balance of metal availability at the cellular level. This may also be true for $\mathrm{S}$ since this nutrient was found in all crystals (Table 3). Although other studies verified the presence of $\mathrm{P}, \mathrm{K}, \mathrm{Mg}$, and $\mathrm{S}$ in crystals, some plant 

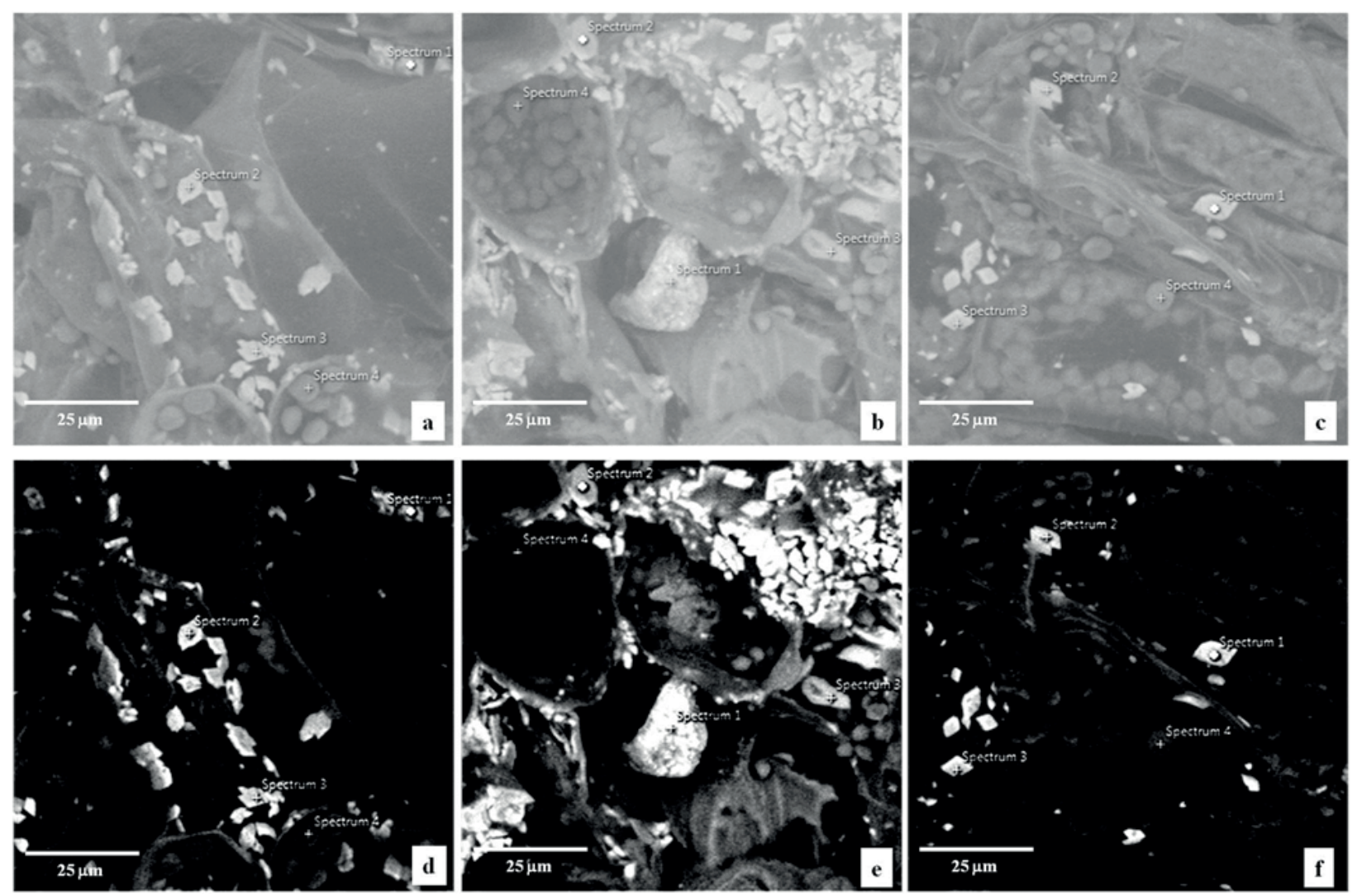

FIGURE 5 Photomicrographs of $A$. angustifolia needle mesophyll. Plants were grown under low P (a; d), low K (b, e) and control conditions (with P and K) (c; f). a-c: photomicrographs taken with a scanning electron microscope at low vacuum. $d$-f: are the same photomicrographs a-c with brightness reduction (-40\%) and increased contrast (80\%). The spectrum indications (I, 2 and 3 [crystals] and 4 [starch granules]) are the points selected to determine elemental composition.

species (i.e., Piper arboreum var. arboreum, $P$. callosum, $P$. tuberculatum, Acacia robeorum, Acacia stipuligera, Acacia stellaticeps, and Fagus sylvatica) have high concentrations of these elements (SILVA et al., 20I4, HE et al., 20I4, KRIEGER et al., 2017).

Although Al was detected in all analyzed crystals (Table 3), one of the needle crystals from the $-K$ treatment was comprised of $2.79 \%$ Al. In addition, Fe (3.82\%) and $\mathrm{Cl}(0.67 \%)$ were detected only in the crystal with a high Al content. This suggests that some crystals are multielement compounds. In the case of $\mathrm{Al}$, the sequestration of this potentially toxic element in the crystal structure can be beneficial to the plant, considering that it would be one means of inactivating $\mathrm{Al}$ and decreasing (at least partially) the harmful effects to leaf physiology. Thus, Al sequestration in crystals can be a means for native acid soil species (e.g., A. angustifolia) to tolerate increased soil Al availability. Furthermore, the accumulation of several other elements ( $\mathrm{Mn}, \mathrm{Cu}, \mathrm{V}, \mathrm{Ti}, \mathrm{Ba}, \mathrm{Sr}, \mathrm{Cd}, \mathrm{Pb}, \mathrm{Fe}, \mathrm{Zn}$ ) in crystals has been reported (HE et al., 20I4; HE et al., 20I5).

Altering photomicrographs $(40 \%$ brightness decrease and $80 \%$ contrast increase) obtained by SEM in low vacuum allowed for better visualization of crystals in A. angustifolia needles (Figure 4d,f). This was only possible because these photomicrographs were obtained under low vacuum without metallization. Image collection in low vacuum causes a chromatic contrast between materials of different composition (e.g., Ca oxalate crystals and plant tissues). When the sample is metallized this chromatic contrast is drastically reduced (Figure I) due to the high atomic number of the metal used in metallization $(\mathrm{Au})$. Thus, the change in the chromatic properties of the photomicrographs only increases the natural contrast between crystals and needle tissues; this contrast is somewhat similar to highlighting crystals by bleaching plant tissue and visualizing with polarized light microscopy (LERSTEN; HORNER, 20I I; SILVA et al., 20I4).

\section{CONCLUSION}

Under low soil $P$ and $K$, these elements were found in low concentrations in the epidermis, mesophyll, and crystals in needles of South American conifer Araucaria angustifolia. Under low soil $\mathrm{K}$ conditions, a higher $\mathrm{Ca}$ concentration increase occurs in the spongy mesophyll and 
TABLE 3 Relative elemental composition (\%) of crystal structures found in the mesophyll of needles from Araucaria angustifolia grown under low $\mathrm{P}(-\mathrm{P})$, low K (-K), and control conditions (with $\mathrm{P}$ and $\mathrm{K}$ ).

\begin{tabular}{|c|c|c|c|c|c|c|c|c|c|c|c|c|}
\hline \multirow{2}{*}{ Elements } & \multicolumn{4}{|c|}{$-P$} & \multicolumn{4}{|c|}{$-K$} & \multicolumn{4}{|c|}{ Control } \\
\hline & $\mathrm{II}^{1}$ & 2 & 3 & 4 & I & 2 & 3 & 4 & I & 2 & 3 & 4 \\
\hline C & 57.31 & 55.30 & 53.01 & 63.83 & 54.51 & 46.97 & 46.98 & 54.97 & 55.26 & 59.12 & 55.42 & 66.21 \\
\hline 0 & 36.08 & 37.67 & 39.55 & 34.13 & 28.80 & 36.66 & 35.93 & 37.29 & 36.70 & 36.76 & 36.33 & 32.15 \\
\hline $\mathrm{Ca}$ & 6.10 & 6.53 & 6.89 & 1.56 & 5.61 & 15.67 & 16.22 & 6.71 & 7.25 & 3.00 & 7.40 & 0.57 \\
\hline $\mathrm{Fe}$ & - & - & - & - & 3.82 & - & - & - & - & - & - & - \\
\hline $\mathrm{Al}$ & 0.20 & 0.20 & 0.19 & 0.21 & 2.79 & 0.21 & 0.29 & 0.30 & 0.48 & 0.62 & 0.48 & 0.50 \\
\hline $\mathrm{Si}$ & - & - & - & - & $2.4 I$ & 0.10 & 0.18 & 0.11 & - & 0.09 & - & - \\
\hline $\mathrm{Cl}$ & - & - & - & - & 0.67 & - & - & - & - & - & - & - \\
\hline $\mathrm{K}$ & 0.16 & 0.13 & 0.15 & 0.14 & 0.50 & - & - & - & 0.11 & 0.15 & 0.08 & 0.13 \\
\hline $\mathrm{S}$ & 0.15 & 0.13 & 0.14 & 0.13 & 0.30 & 0.13 & 0.12 & 0.22 & 0.12 & 0.16 & 0.15 & 0.20 \\
\hline$P$ & - & - & - & - & 0.27 & 0.09 & 0.12 & 0.20 & - & 0.11 & 0.12 & 0.18 \\
\hline $\mathrm{Mg}$ & - & - & - & - & 0.16 & 0.15 & 0.17 & 0.20 & - & - & - & - \\
\hline $\mathrm{Na}$ & - & - & 0.06 & - & 0.16 & - & - & - & 0.08 & - & - & 0.08 \\
\hline Total & 100 & 100 & 100 & 100 & 100 & 100 & 100 & 100 & 100 & 100 & 100 & 100 \\
\hline
\end{tabular}

' The numbers I, 2, 3, and 4 correspond to the points (spectrum) indicated in Figure 5 by using the same numbering scheme.

more crystals containing $\mathrm{Ca}$ and $\mathrm{Mg}$ are formed. Under low $\mathrm{P}$ conditions, $\mathrm{K}$ and $\mathrm{Ca}$ accumulated in the spongy mesophyll with a small increase in crystal formation. Therefore, the availability of $\mathrm{P}$ and $\mathrm{K}$ in soil affected the accumulation of elements in needles and the type of tissue and formation of crystals were key to the nutrient dynamics in needles of this South American conifer.

\section{ACKNOWLEDGMENTS}

Center of Electronic Microscopy of the Federal University of Paraná (CME-UFPR).

\section{REFERENCES}

CARR, H.; LOMBI, E.; KÜPPER, H.; McGRATH, S.; WONG, $M$. Accumulation and distribution of aluminium and other elements in tea (Camellia sinensis) leaves. Agronomie, v. 23, n. 8, p. 705-710, 2003.

CARVALHO, M. R.; WOLL, A.; NIKLAS, K. J. Spatiotemporal distribution of essential elements through Populus leaf ontogeny. Journal of experimental botany, v. 67, n. 9, p. 2777-2786, 2016.

CASSANA, F. F.; DILLENBURG, L. R. The periodic wetting of leaves enhances water relations and growth of the longlived conifer Araucaria angustifolia. Plant Biology,v. I5, n. I, p. 75-83, 20I3.

CONN, S.; GILLIHAM, M. Comparative physiology of elemental distributions in plants. Annals of Botany, v. 105, n. 7, p. $1081-1102,2010$.

COMISSÃO DE QUÍMICA E FERTILIDADE DO SOLO - RS/ SC. Manual de adubação e calagem para os Estados do Rio Grande do Sul e Santa Catarina. I0. Ed, 2004, p. 40 I.

DINH, N.; VU, D. T.; MULLIGAN, D.; NGUYEN, A. V. Accumulation and distribution of zinc in the leaves and roots of the hyperaccumulator Noccae caerulescens. Environmental and Experimental Botany, v. I10, p. 85-95, 2015.
EMPRESA BRASILEIRA DE PESQUISA AGROPECUÁRIAEMBRAPA. Manual de métodos de análise de solo. 2. ed. Embrapa Solos, 201 I, p. 225.

FERREIRA, D. F. Sisvar: a computer statistical analysis system. Ciência e Agrotecnologia, v. 35, n. 6, p. 1039 1042, 2011.

FINK, S. The micromorphological distribution of bound calcium in needles of Norway spruce [Picea abies (L.) Karst.]. New Phytologist, v. I19, n. I, p 33-40, 1991.

GARBIN, M. L.; DILLENBURG, L. R. Effects of different nitrogen sources on growth, chlorophyll concentration, nitrate reductase activity and carbon and nitrogen distribution in Araucaria angustifolia. Brazilian Society of Plant Physiology, v. 20, n. 4, p. 295-303, 2008.

HE, H.; VENEKLAAS, E. J.; KUO, J.; LAMBERS, H. Physiological and ecological significance of biomineralization in plants. Trends in Plant Science, v. 19, n. 3, p. 166-174, 2014.

HE, H.;KIRILAK, Y.; KUO, J.; LAMBERS, H. Accumulation and precipitation of magnesium, calcium, and sulfur in two Acacia (Leguminosae; Mimosoideae) species grown in different substrates proposed for mine-site rehabilitation. American Journal of Botany, v. 102, n. 2, p. 290-301, 2015.

KARLEY, A. J.; LEIGH, R. A.; SANDERES, D. Where do all the ions go? The cellular basis of differential ion accumulation in leaf cells. Trends in Plant Science, v. 5, n. I I, p. 465-470, 2003.

KRIEGER, C.; CALVARUSO, C.; MORLOT, C.; UROZ, S.; SALSI, L.; TURPAULT, M. P. Identification, distribution, and quantification of biominerals in a deciduous forest. Geobiology, v. I5, n. 2, p. 296-310, 2017.

LEITENMAIER, B.; KÜPPER, H. Compartmentation and complexation of metals in hyperaccumulator plants. Frontiers in Plant Science, v. 4, p. I-I3, 2013. 
LERSTEN, N. R.; HORNER, H. T. Unique calcium oxalate "duplex" and "concretion" idioblasts in leaves of tribe Naucleeae (Rubiaceae). American Journal of Botany, v. 98, n. I, p. I-II, 201 I.

MASTROBERTI, A.A.; MARIATH, J.E.A. Leaf anatomy of Araucaria angustifolia (Bertol.) Kuntze (Araucariaceae). Revista Brasileira de Botânica, v. 26, n. 3, p. 343-353, 2003.

PERALTA, R. M.; KOEHNLEIN, E. A.; OLIVEIRA, R. F.; CORREA, V. G.; CORRÊA, R. C. G.; BERTONHA, L.; BRACHT, A.; FERREIRA, I. C. F. R. Biological activities and chemical constituents of Araucaria angustifolia: An effort to recover a species threatened by extinction. Trends in Food Science \& Technology, v. 54, p. 85-93, 2016.

PRITCHARD, S. G.; PRIOR, S. A.; ROGERS, H. H.; PETERSON, C. M. Calcium sulfate deposits associated with needle substomatal cavities of container grown longleaf pine (Pinus palustris). International Journal of Plant Science, v. 16I, n. 6, p. 917-923, 2000.

REGVAR, M.; EICHERT, D.; KAULICH, B.; GIANONCELLI, A.; PONGRAC, P.; VOGEL-MIKUŠ, K. Biochemical characterization of cell types within leaves of metalhyperaccumulating Noccaea praecox (Brasicaceae). Plant and Soil, v. 373, n. I-2, p. I57-I7I, 2013.

REIS, M. S.; LADIO, A.; PERONI, N. Landscapes with Araucaria in South America: evidence for a cultural dimension. Ecology and Society, v. 19, n. 2, 2014.

REISSMANN, C.B.; HILDEBRAND, E.E.; BLUM, W.E.H.; BURGER, L.M. Metodologia da amostragem e análise das acículas da Araucaria angustifolia Bert. O. Ktze. Revista Floresta, v. 7, n. I, p. 5-12, 1976.
RIOS, J. J.; LOCHLAINN, S. Ó.; DEVONSHIRE, J.; GRAHAM, N. S.; HAMMOND, J. P.; KING, G. J.; WHITE, P.J.; KURUP, S.; BROADLEY, M. R. Distribution of calcium (Ca) and magnesium (Mg) in the leaves of Brassica rapa under varying exogenous $\mathrm{Ca}$ and $\mathrm{Mg}$ supply. Annals of Botany, v. 109, n. 6, p. $1081-1989,2012$.

SILVA, R. J. F; AGUIAR-DIAS, A. C. A.; MENDONÇA, M. S. Rosetas e concrescências cristalinas silicificadas em Piper (Piperaceae): registros inéditos de macropadrões. Acta Amazonica, v. 44, n. 4, p. 435-446, 2014.

SIMÕES, J. W.; COUTO, H. T. Z. Efeitos da omissão de nutrientes na alimentação mineral do pinheiro do Paraná Araucaria angustifolia (Bert) O.KTZE cultivado em vaso. Instituto de Pesquisas Florestais, v. 7, p. 3-39, 1973.

TAIZ, L.; ZEIGER, E.; MØLLER, I. M.; MURPHY, A. Plant physiology and development. Sinauer Associates, 2015 , p. 761 .

VOGEL-MIKUŠ, K.; SIMCIC, J.; PELICON, P.; BUDNAR, M.; KUMP, P.; NECEMER, M.; MESJASZ-PRZYBYŁOWICZ, J.; PRZYBYŁOWICZ, W. J.; REGVAR, M. Comparison of essential and non-essential element distribution in leaves of the $\mathrm{Cd} / \mathrm{Zn}$ hyperaccumulator Thlaspi praecox as revealed by micro-PIXE. Plant, Cell and Environment, v. 3I, n. I0, p. |484-| 496, 2008.

WHITE, P. J. Calcium. In: BROADLEY, M. R.; WHITE, P. J. Plant Nutritional Genomics. Blackwell, Oxford, UK, 2005, p. 66-86. 
